\title{
Degradation of Phenothrin in Stored Wheat Grains
}

\author{
Kenji Nambu, Yoshiyuki Takimoto and Junshi Miyamoto \\ Research Department, Pesticides Division, Sumitomo Chemical Co., Ltd., \\ Takarazuka, Hyogo 665, Japan
}

(Received October 11, 1980)

\begin{abstract}
${ }^{14} \mathrm{C}$-Labeled $(+)$-trans and $(+)$-cis isomers of phenothrin [3-phenoxybenzyl $( \pm)$-cis, trans-chrysanthemate] were each applied at the concentration of $4 \mathrm{ppm}$ to wheat grains with $11 \%$ moisture content, and stored at 15 or $30^{\circ} \mathrm{C}$ in the dark. Both trans and cis isomers were decomposed slowly, and 79 and $87 \%$ of the applied radiocarbon remained intact in the grains after 12 -month storage at $30^{\circ} \mathrm{C}$, respectively. Both isomers were majorly metabolized via hydrolysis of ester linkage, oxidation of the benzyl alcohol to the benzoic acid and methylation of the benzoic acid. The joint application with piperonyl butoxide and fenitrothion inhibited the degradation of phenothrin isomers to some extent. The phenothrin isomers and their decomposition products were mainly located at seed coat during 12-month storage, and the residue levels of both isomers in flour and bran were 0.77 and $11.4 \mathrm{ppm}$, respectively. The phenothrin residues in flour somewhat decreased through the baking process, leaving $0.57 \mathrm{ppm}$ of phenothrin isomers in bread. These findings were compared with those of ${ }^{14} \mathrm{C}$-malathion which was rapidly decomposed to desmethylmalathion, malathion-monoacids, -diacid and ${ }^{14} \mathrm{CO}_{2}$, with respective half-lives of 8 and 1.1 months at 15 and $30^{\circ} \mathrm{C}$.
\end{abstract}

\section{INTRODUCTION}

Phenothrin [3-phenoxybenzyl $( \pm)$-cis, transchrysanthemate] is one of the new synthetic pyrethroids and currently used in household, public health and livestock production because of its outstanding insecticidal activity and its extremely low acute mammalian toxicity. ${ }^{1}$ Recently this insecticide proved to have an advantage over pyrethrins and bioresmethrin in cost/efficiency and reliable availability as a potential grain protectant. ${ }^{2,3)}$ This compound combined with piperonyl butoxide and fenitrothion was found to control a broad spectrum of insect pests including organophosphorus-resistant strains. ${ }^{2,3)}$ Although metabolic fates of phenothrin in rats, ${ }^{4-6)}$ plants $^{7)}$ and soil ${ }^{7)}$ were already established, its fate in stored grains has not been clarified. This report deals with the degradation and distribution of $(+)$-trans and $(+)$-cis isomers of phenothrin in stored wheat grains and also their decomposition through processing and cooking.

\section{MATERIALS AND METHODS}

\section{Chemicals}

$(+)$-Trans and $(+)-c i$ s isomers of phenothrin labeled with ${ }^{14} \mathrm{C}$ at benzyl-methylene carbon in the alcohol moiety were synthesized by Hazue and Kamata ${ }^{8)}$ of Sumitomo Chemical Co. The specific activity of both preparations was $7.3 \mathrm{mCi} / \mathrm{mmole}$ with radiochemical purity of more than $99 \%$, as evidenced by thin-layer chromatography $(t l c)$. Malathion [O,O-dimethyl $S$-(1,2-dicarboethoxy)ethyl phosphorodithioate] labeled with ${ }^{14} \mathrm{C}$ at 1,2-ethyl positions was purchased from Radiochemical Centre, Amersham, England and its specific activity was $2.78 \mathrm{mCi} / \mathrm{mmole}$ with radiochemical purity of $98 \%$.

The following unlabeled authentic compounds were synthesized in the authors' laboratory ${ }^{4,7,9)}$ : 3-phenoxybenzyl (+)-transchrysanthemate $[t$-phenothrin], 3-phenoxybenzyl $(+)$-cis-chrysanthemate [c-phenothrin], 3-phenoxybenzyl alcohol [PBalc], 3phenoxybenzoic acid [PBacid], methyl 3phenoxybenzoate [PBacid-Me], 3-phenoxybenzyl (+)-2,2-dimethyl-3-trans-formyl-cy- 
clopropane-1-carboxylate [formyl- $t$-phenothrin], 3-phenoxybenzyl (+)-2,2-dimethyl-3cis-formyl-cyclopropane-1-carboxylate [formyl-c-phenothrin], malathion, $O$-hydrogen $O$ methyl $S$-(1,2-dicarboethoxy)ethyl phosphorodithioate [desmethylmalathion], $O, O-$ dimethyl $S$-(1-carboxy-2-carboethoxy) ethyl phosphorodithioate [malathion $\alpha$-monoacid], O,O-dimethyl S-(1-carboethoxy-2-carboxy)ethyl phosphorodithioate [malathion $\beta$-monoacid], $O, O$-dimethyl $S$-(1,2-dicarboxy)ethyl phosphorodithioate [malathion diacid].

Piperonyl butoxide [PBO] with the purity of $98.4 \%$ was purchased from Takasago Perfumery Co., Hiratsuka, Japan. Fenitrothion or Sumithion ${ }^{\circledR}[O, O$-dimethyl $O-(3-$ methyl-4-nitrophenyl) phosphorothioate] of technical grade with the purity of $96.8 \%$ was synthesized by Sumitomo Chemical Co. ${ }^{14} \mathrm{C}-$ $t$-phenothrin, ${ }^{14} \mathrm{C}-\mathrm{c}$-phenothrin or ${ }^{14} \mathrm{C}$-malathion in emulsion was prepared as follows; the ${ }^{14} \mathrm{C}$-preparation, Sorpol $3005 \mathrm{X}$ (Toho Chemical Co., Tokyo, Japan) and xylene were mixed at the rate of $1 / 1 / 9(\mathrm{w} / \mathrm{w})$, and diluted suitably with water. An emulsion of ${ }^{14} \mathrm{C}$ phenothrin plus $\mathrm{PBO}$ or ${ }^{14} \mathrm{C}$-phenothrin plus PBO plus fenitrothion was also prepared from each mixture of ${ }^{14} \mathrm{C}$-phenothrin-PBO-Sorpol $3005 \mathrm{X}$-xylene $(1 / 5 / 1 / 9)$ and ${ }^{14} \mathrm{C}$-phenothrin-PBO-fenitrothion-Sorpol $3005 \mathrm{X}$-xylene $(1 / 5 / 1 / 1 / 9)$.

\section{Treatment of Wheat Grains}

Wheat grains, variety Horoshiri, harvested in Hokkaido, Japan, in August, 1978, with residues of less than the detectable amount $(2 \mathrm{ppb})$ of both malathion and fenitrothion were kept at $20 \pm 2^{\circ} \mathrm{C}$ for 3 weeks over saturated magnesium nitrate solution to adjust the moisture content to $10.5 \%$. The grains were treated with each ${ }^{14} \mathrm{C}$-preparation in emulsion at the rate of $1 \%$ relative to grain weight in October, 1978, then mixed well and air-dried. The application rates of phenothrin, phenothrin plus $\mathrm{PBO}$, phenothrin plus $\mathrm{PBO}$ plus fenitrothion and malathion were $4,4+20$, $4+20+4$ and $15 \mathrm{ppm}$, respectively. Each treated sample was placed in a stoppered glass vessel (i.d. $14 \mathrm{~cm}$, height $14 \mathrm{~cm}$ ) and kept at $15 \pm 2$ or $30 \pm 2^{\circ} \mathrm{C}$ in the dark. To trap the volatile radioactive products, a $50-\mathrm{ml}$ beaker containing $30 \mathrm{ml}$ of $6 \mathrm{~N}$ potassium hydroxide solution was placed inside each vessel.

The moisture content of the wheat grains was measured at intervals by keeping them at $120^{\circ} \mathrm{C}$ for $4 \mathrm{hr}^{10}{ }^{10}$ Immediately after application of the ${ }^{14} \mathrm{C}$-preparations, the moisture content of the grains was $11.0 \%$. Thereafter it gradually increased with time, amounting to 12.8 and $12.0 \%$ at 15 and $30^{\circ} \mathrm{C}$ after 12 months, respectively.

\section{Analysis of Phenothrin Isomers, Mala- thion, Fenitrothion and Their Metabolites in Wheat Grains}

At specified intervals a $10 \mathrm{~g}$-aliquot of wheat grains was powdered with a mill (Kyoritsu-Riko Co., Tokyo, Japan) for $2 \mathrm{~min}$ and $30 \mathrm{ml}$ methanol was added. The mixture was mechanically shaken and kept standing overnight at $4^{\circ} \mathrm{C}$. The solvent phase was separated by centrifugation and the residue was extracted further four times with $30 \mathrm{ml}$ methanol. The combined methanol extracts were analyzed for ${ }^{14} \mathrm{C}$ and metabolites by liquid scintillation counting and $t l c$ as reported previously. ${ }^{7)}$ The tlc $R f$ values for phenothrin isomers, malathion and their metabolites are listed in Table 1.

To observe grossly the distribution of radiocarbon, the grains were embedded in paraffin and cut transversely and longitudinally, then the sections were exposed to $\mathrm{X}$-ray films for two weeks. ${ }^{11)}$

For determination of fenitrothion residues in the grains, aliquots of methanol extracts obtained above were subjected to gas-liquid chromatography in the following conditions: apparatus; Shimadzu GC-5A equipped with $\mathrm{KBr}$ single crystal $\mathrm{FTD},{ }^{12)}$ column; 5\% XE-60 on Gas Chrom Q (100-120 mesh) packed into $\phi 3 \mathrm{~mm} \times l 1.0 \mathrm{~m}$ glass column, gas; carrier gas (He) $48 \mathrm{ml} / \mathrm{min}$, hydrogen $27 \mathrm{ml} / \mathrm{min}$, air 0.3 $l /$ min, temperature; column $186^{\circ} \mathrm{C}$, injection port $275^{\circ} \mathrm{C}$. The retention time of fenitrothion was $3.6 \mathrm{~min}$.

\section{Decomposition of Phenothrin Isomers through Processing and Cooking}

The flour and bran were prepared as in the following. Thirty-five grams of the grains were mixed with $2 \mathrm{ml}$ of distilled water and stirred with a glass rod to peel off pericarps 
Table $1 T l c R f$ values for phenothrin isomers, malathion and their metabolites.

\begin{tabular}{lccccccccc}
\hline \multirow{2}{*}{ Compound } & \multicolumn{10}{c}{$R f$ in solvent systems ${ }^{\mathrm{a}}$ ) } \\
\cline { 2 - 11 } & $\mathrm{A}$ & $\mathrm{B}$ & $\mathrm{C}$ & $\mathrm{D}$ & $\mathrm{E}$ & $\mathrm{F}$ & $\mathrm{G}$ & $\mathrm{H}$ & $\mathrm{I}$ \\
\hline$c$-Phenothrin & 0.61 & 0.54 & 0.68 & 0.47 & & & & & \\
$t$-Phenothrin & 0.59 & 0.54 & 0.68 & 0.43 & & & & & \\
Formyl- $c$-phenothrin & 0.36 & 0.31 & 0.55 & & & & & & \\
Formyl-t-phenothrin & 0.38 & 0.30 & 0.57 & & & & & & \\
PBalc & 0.26 & 0.19 & 0.35 & & & & & & \\
PBacid & 0.34 & 0.05 & 0.46 & & & & & & \\
PBacid-Me & 0.48 & 0.43 & 0.60 & & & & & & \\
Malathion & & & & & 0.62 & 0.63 & 0.61 & 0.63 & 0.86 \\
Malathion $\alpha$-monoacid & & & & & 0.45 & 0.46 & 0.40 & 0.34 & 0.76 \\
Malathion $\beta$-monoacid & & & & & 0.46 & 0.47 & 0.43 & 0.40 & 0.76 \\
Malathion diacid & & & & & 0.24 & 0.36 & 0.23 & 0.18 & 0.62 \\
Desmethylmalathion & & & & & 0.06 & 0.16 & 0.02 & 0.07 & 0.40 \\
\hline
\end{tabular}

a) A: $n$-hexane/toluene/acetic acid $(3 / 15 / 2, \mathrm{v} / \mathrm{v}), \mathrm{B}: n$-hexane/acetone $(4 / 1), \mathrm{C}$ : benzene saturated with formic acid/ether (10/3), D: $n$-hexane/ether (50/1), 7 developments, E: benzene saturated with formic acid/ethyl acetate/acetic acid (8/2/1), F: toluene/ethyl formate/formic acid (5/7/1), $\mathrm{G}$ : benzene/ether/acetic acid (8/2/1), H: benzene/ethyl acetate/acetic acid (50/50/3), I: toluene/ ethyl acetate/isopropanol/acetic acid $(8 / 12 / 5 / 3)$.

from the grains. Germs were separated from the peeled grains by picking them up with a pincette. Then the grains were powdered with a coffee mill (Nihon Philips Co., Tokyo, Japan) for $2 \mathrm{~min}$ and the powdered endosperm (flour) was obtained by passing through a 100mesh sieve to separate from aleurone layers. The germs, pericarps and aleurone layers were combined and the fraction was designated as bran. Each flour and bran fraction was extracted with methanol and analyzed as described above.

The bread was prepared as follows. Dry yeast $(0.3 \mathrm{~g})$, sugar $(1.1 \mathrm{~g})$, salt $(0.27 \mathrm{~g})$, skim milk $(0.5 \mathrm{~g})$, butter $(1.0 \mathrm{~g})$ and distilled water $\left(12 \mathrm{ml}, 40^{\circ} \mathrm{C}\right)$ were added to the flour $(20 \mathrm{~g})$, then mixed well and subjected to fermentation (1st, $37^{\circ} \mathrm{C}$ for $60 \mathrm{~min}$; $2 \mathrm{nd}, 37^{\circ} \mathrm{C}$ for $30 \mathrm{~min}$ ) and baking $\left(200^{\circ} \mathrm{C}\right.$ for $\left.30 \mathrm{~min}\right)$ with an oven (Type TO-120, Hitachi, Tokyo, Japan). The bread was powdered with a mill and extracted with methanol using a Polytron ${ }^{\circledR}$ (Kinematica $\mathrm{GmbH}$, Luzern, Steinhofhalde, Switzerland). The methanol extracts were concentrated and then were partitioned between acetonitrile and petroleum ether. The acetonitrile layer was analyzed as described above.

All experiments were duplicated. The results are shown as the average values of the duplicate experiments.

\section{RESULTS}

\section{Degradation of Phenothrin Isomers in Stored Wheat Grains}

As shown in Fig. 1, both isomers of phenothrin were decomposed slowly in the grains even at higher temperature storage. After 12 -month storage at $30^{\circ} \mathrm{C}, 79$ and $87 \%$ of the applied radiocarbon were recovered as intact $t$ - and $c$-phenothrin, respectively, and $t$ -

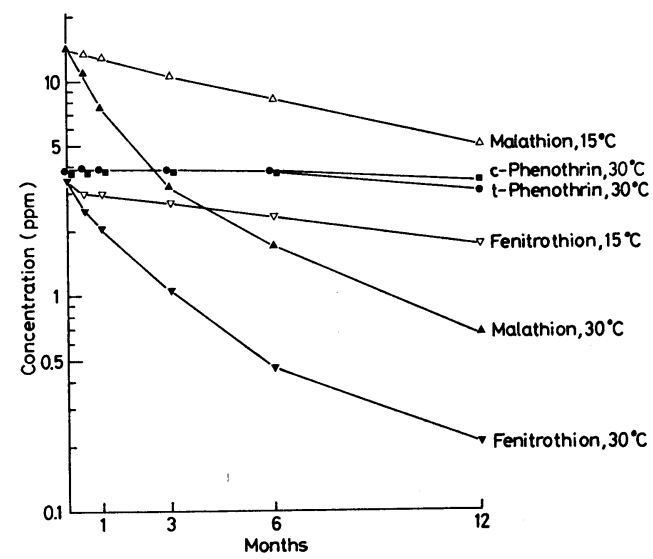

Fig. 1 Residue amounts of phenothrin isomers, malathion and fenitrothion in wheat grains stored at $15^{\circ} \mathrm{C}$ and $30^{\circ} \mathrm{C}$. 


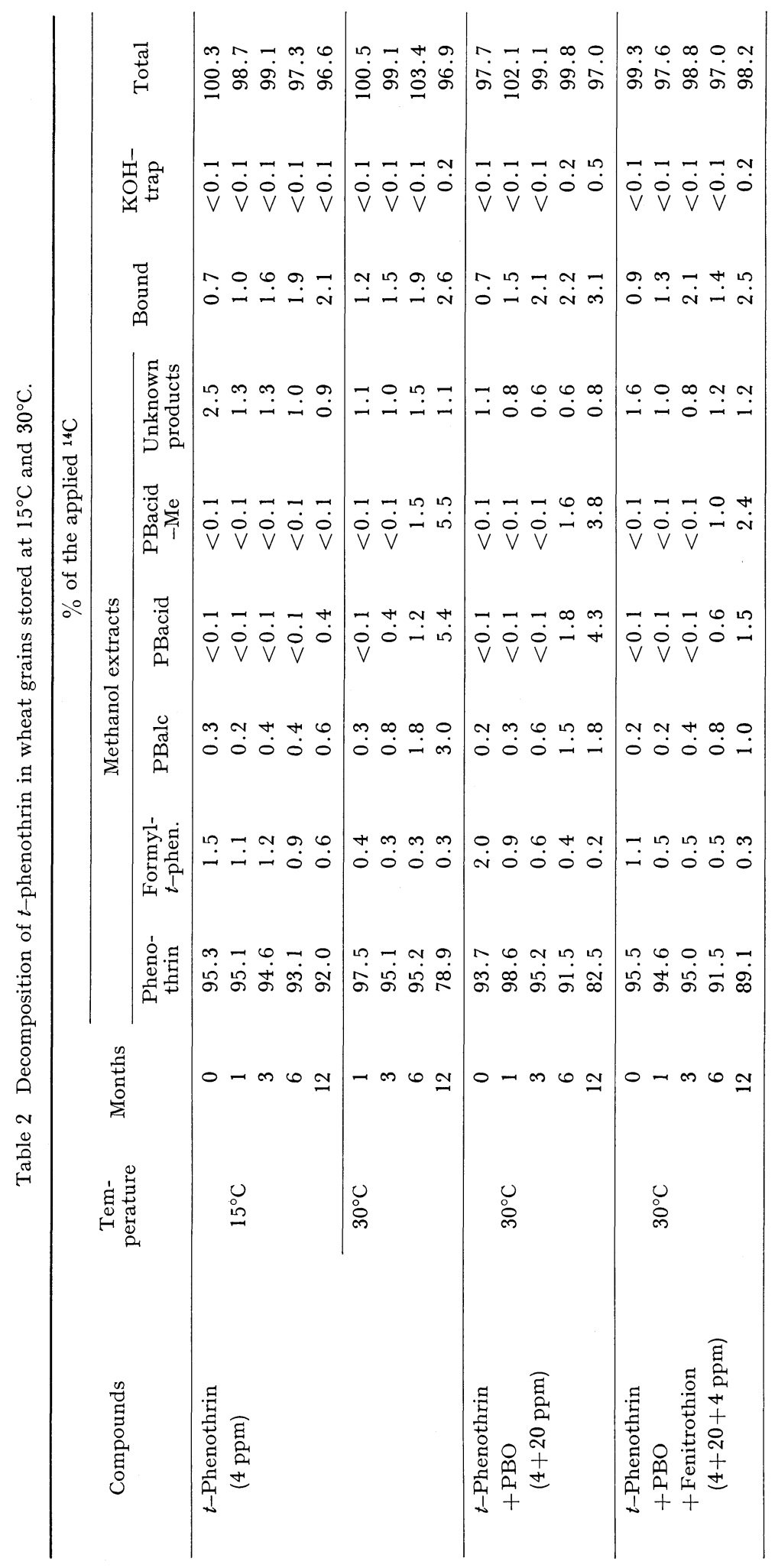




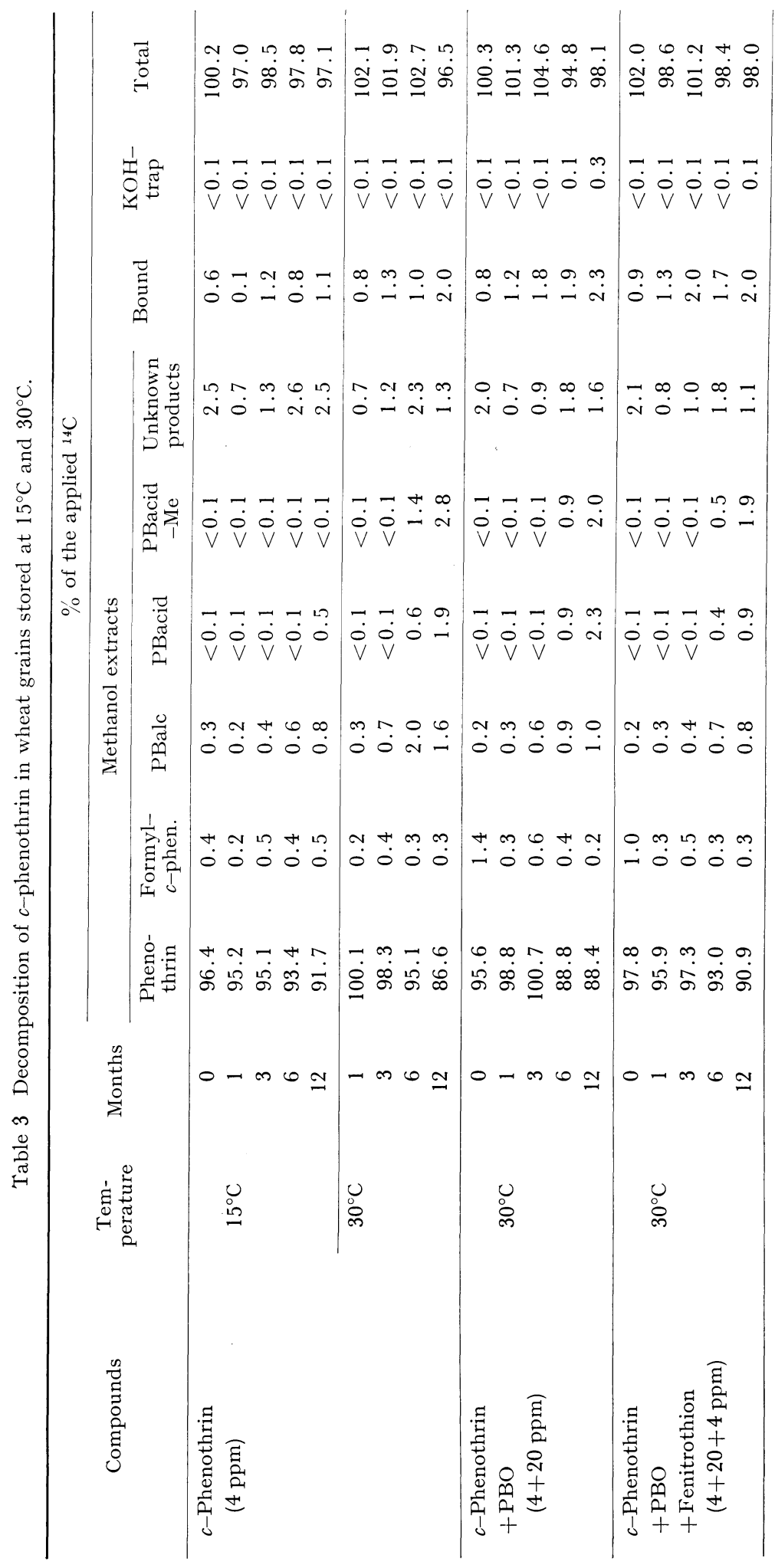




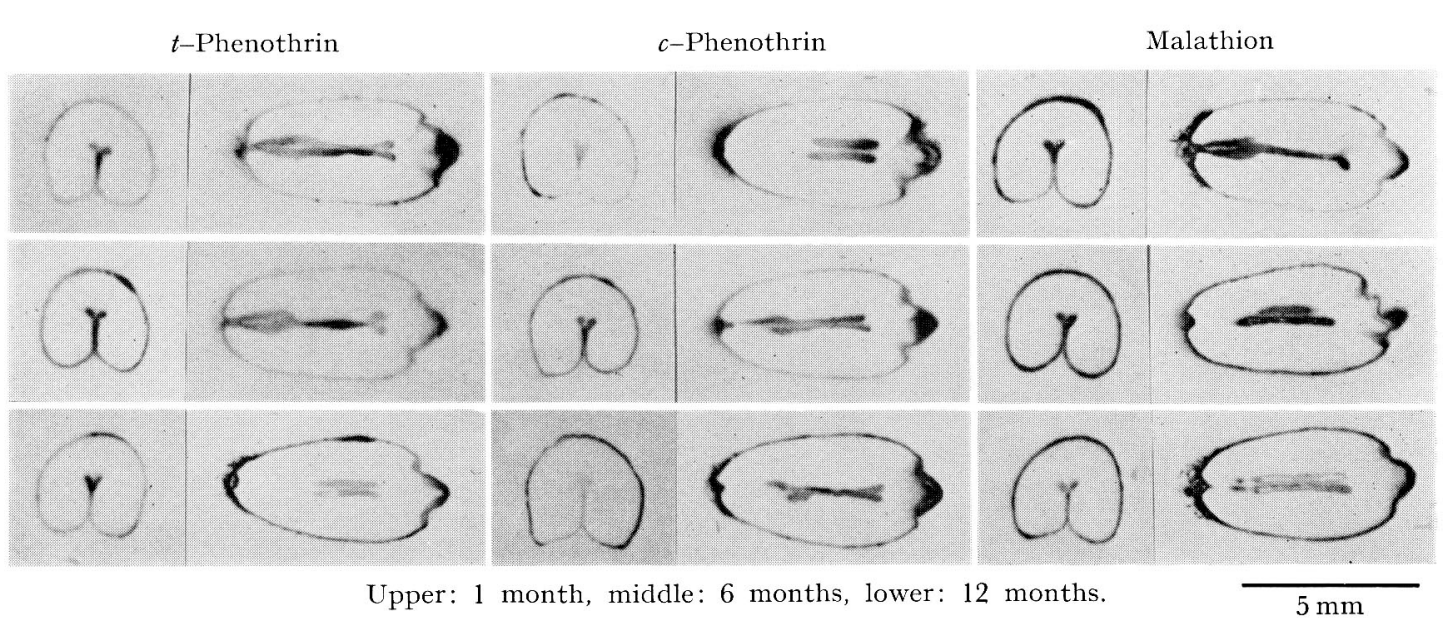

Fig. 2 Radioautograms of transverse and longitudinal sections of wheat grains treated with ${ }^{14} \mathrm{C}-$ phenothrin isomers and ${ }^{14} \mathrm{C}$-malathion and stored at $30^{\circ} \mathrm{C}$ for 1,6 and 12 months.

phenothrin was somewhat more degradable than $c$-phenothrin (Tables 2 and 3). At lower temperature storage, decomposition of both isomers was negligible. The joint application of phenothrin isomers with $\mathrm{PBO}$ or PBO plus fenitrothion did not significantly affect the residual lives of both isomers for up to 6 months. But after 12 months, PBO and PBO plus fenitrothion gave the higher recovery of $t$-phenothrin by 4 and $10 \%$ of the applied radiocarbon at $30^{\circ} \mathrm{C}$, respectively. This tendency was also observed in the case of $c$-phenothrin.

The degradation products obtained from phenothrin isomers were isolated and then identified by two-dimensional $t l c$ cochromatography with authentic standards. PBacid-Me was further confirmed not to be an artifact by extraction with acetone or benzene instead of methanol. Among these products identified, ester-hydrolyzed products such as PBalc, PBacid and PBacid-Me increased gradually, and the sum of these metabolites amounted to $6-14 \%$ after 12 -month incubation at $30^{\circ} \mathrm{C}$. These metabolites were produced in larger amonts from trans isomer than cis isomer and also at $30^{\circ} \mathrm{C}$ than $15^{\circ} \mathrm{C}$. $\mathrm{PBO}$ and $\mathrm{PBO}$ plus fenitrothion decreased the production of these metabolites by $1-4$ and $3-9 \%$ of the applied radiocarbon after 12 months, respectively. Other than the above decomposition products, formyl- $t$ - and formyl-c-phenothrin were produced at the early stage of incubation, amounting maximally to $2 \%$ of the applied radiocarbon, but their contents decreased with time. Unknown products which contained at least five spots on $t l c$, and volatile radioactive products were detected in small amounts.

\section{Distribution of ${ }^{14} \mathrm{C}$ in Wheat Grains and Decomposition of Phenothrin Isomers} through Processing and Cooking

As shown in Fig. 2, the distribution of radiocarbon in wheat grains did not change substantially during 12 -month storage. The radiocarbon was mainly located at seed coat including the crease area, while relatively little radiocarbon was found in germ and endosperm regions. Actually the contents of phenothrin isomers in flour obtained with our milling procedure were 13 to 15 times lower than those in bran (Table 4). Furthermore the phenothrin residues in flour decreased through the baking process to some extent. No trans/ cis isomerization was observed during baking. Most of the decomposition products in bread were ester-hydrolyzed products, and c-formylphenothrin was detected in a trace amount (Table 5). 
Table 4 Residues of phenothrin isomers prior to and following processing and cooking.

\begin{tabular}{|c|c|c|c|c|}
\hline & \multicolumn{4}{|c|}{ Content, $\mathrm{ppm}^{\mathrm{a})}$} \\
\hline & \multicolumn{2}{|c|}{$t$-Phenothrin } & \multicolumn{2}{|c|}{$c$-Phenothrin } \\
\hline & \multicolumn{4}{|c|}{ Storage period (months) } \\
\hline & 6 & 12 & 6 & 12 \\
\hline Wheat grain ${ }^{b}$ ) & 3.78 & 3.13 & 3.64 & 3.32 \\
\hline Flour & $0.79(73 \%)^{\mathrm{c})}$ & $0.76(76 \%)$ & $0.77(72 \%)$ & $0.77(75 \%)$ \\
\hline Bran & $11.4 \quad(27 \%)$ & $11.3(24 \%)$ & $9.75(28 \%)$ & $11.4(25 \%)$ \\
\hline Bread & 0.69 & 0.57 & 0.66 & 0.57 \\
\hline
\end{tabular}

a) $\mu \mathrm{g}$ phenothrin /g (wet weight).

b) The wheat grains were treated with ${ }^{14} \mathrm{C}$-phenothrin isomers at $4 \mathrm{ppm}$ alone and stored at $30^{\circ} \mathrm{C}$ in the dark.

c) Wet weight ratio of milled fractions.

Table 5 Contents of phenothrin isomers and their decomposition products in flour and bread.

\begin{tabular}{|c|c|c|c|c|c|c|c|c|}
\hline \multirow{2}{*}{ Compound } & & \multirow{2}{*}{$\begin{array}{l}\text { Storage } \\
\text { period } \\
\text { (months) }\end{array}$} & \multicolumn{6}{|c|}{ Content, $\mathrm{ppm}^{\mathrm{a}}$} \\
\hline & & & $\begin{array}{l}\text { Pheno- } \\
\text { thin }\end{array}$ & $\begin{array}{c}\text { Formyl- } \\
\text { phenothrin }\end{array}$ & PBalc & PBacid & $\begin{array}{c}\text { PBacid- } \\
\mathrm{Me}\end{array}$ & $\begin{array}{l}\text { Unknown } \\
\text { products }\end{array}$ \\
\hline \multirow[t]{4}{*}{$t$-Phenothrin } & Flour & 6 & 0.79 & $<0.01$ & 0.02 & 0.01 & 0.01 & 0.01 \\
\hline & & 12 & 0.76 & $<0.01$ & 0.03 & 0.06 & 0.08 & 0.04 \\
\hline & Bread & 6 & 0.69 & $<0.01$ & 0.03 & 0.02 & 0.01 & 0.04 \\
\hline & & 12 & 0.57 & $<0.01$ & 0.02 & 0.03 & 0.05 & 0.03 \\
\hline \multirow[t]{4}{*}{$c$-Phenothrin } & Flour & 6 & 0.77 & 0.02 & 0.01 & 0.01 & $<0.01$ & 0.02 \\
\hline & & 12 & 0.77 & 0.01 & 0.01 & 0.02 & 0.03 & 0.02 \\
\hline & Bread & 6 & 0.66 & 0.02 & 0.03 & 0.01 & 0.01 & 0.03 \\
\hline & & 12 & 0.57 & 0.01 & 0.01 & 0.01 & 0.01 & 0.03 \\
\hline
\end{tabular}

a) $\mu \mathrm{g}$ phenothrin equivalent/g flour or bread (wet weight).

Table 6 Decomposition of malathion in wheat grains stored at $15^{\circ} \mathrm{C}$ and $30^{\circ} \mathrm{C}$.

\begin{tabular}{|c|c|c|c|c|c|c|c|c|c|c|}
\hline \multirow[b]{3}{*}{$\begin{array}{l}\text { Tempera- } \\
\text { ture }\end{array}$} & \multirow[b]{3}{*}{ Months } & \multicolumn{9}{|c|}{$\%$ of the applied ${ }^{14} \mathrm{C}$} \\
\hline & & \multicolumn{5}{|c|}{ Methanol extracts } & \multirow[b]{2}{*}{ Bound } & \multicolumn{3}{|c|}{ KOH-trap } \\
\hline & & $\begin{array}{l}\text { Mala- } \\
\text { thion }\end{array}$ & $\begin{array}{l}\text { Mala- } \\
\text { thion } \\
\text { mono- } \\
\text { acids }\end{array}$ & $\begin{array}{l}\text { Mala- } \\
\text { thion } \\
\text { diacid }\end{array}$ & $\begin{array}{l}\text { Des- } \\
\text { methyl } \\
\text { mala- } \\
\text { thion }\end{array}$ & $\begin{array}{c}\text { Un- } \\
\text { known } \\
\text { products }\end{array}$ & & ${ }^{14} \mathrm{CO}_{2}$ & $\begin{array}{c}\text { Un- } \\
\text { known } \\
\text { products }\end{array}$ & Total \\
\hline & 0 & 94.0 & 1.7 & $<0.1$ & 0.4 & 2.3 & 1.5 & $<0.1$ & $<0.1$ & 99.9 \\
\hline \multirow[t]{5}{*}{$15^{\circ} \mathrm{C}$} & $1 / 2$ & 88.9 & 2.9 & $<0.1$ & 2.4 & 1.9 & 2.7 & $<0.1$ & 0.1 & 98.9 \\
\hline & 1 & 86.0 & 4.1 & 0.3 & 4.5 & 2.0 & 3.7 & $<0.1$ & 0.2 & 100.8 \\
\hline & 3 & 71.2 & 6.6 & 0.2 & 9.5 & 2.8 & 7.6 & 0.3 & 0.5 & 98.7 \\
\hline & 6 & 54.2 & 8.0 & 0.7 & 15.9 & 3.0 & 11.8 & 0.5 & 1.2 & 95.3 \\
\hline & 12 & 34.2 & 7.4 & 0.5 & 21.8 & 5.1 & 20.3 & 1.0 & 2.0 & 92.3 \\
\hline \multirow[t]{5}{*}{$30^{\circ} \mathrm{C}$} & $1 / 2$ & 72.3 & 6.1 & 0.3 & 10.9 & 3.5 & 9.4 & 0.6 & 0.5 & 103.6 \\
\hline & 1 & 49.9 & 6.0 & 0.5 & 19.6 & 3.4 & 14.4 & 1.3 & 1.0 & 96.1 \\
\hline & 3 & 21.5 & 4.0 & 0.5 & 26.9 & 6.3 & 31.3 & 2.3 & 1.9 & 94.7 \\
\hline & 6 & 11.0 & 2.4 & 0.8 & 29.0 & 8.8 & 37.8 & 3.8 & 2.1 & 95.7 \\
\hline & 12 & 4.5 & 1.8 & 0.4 & 23.5 & 9.1 & 50.3 & 6.2 & 2.5 & 98.3 \\
\hline
\end{tabular}


3. Degradation of Fenitrothion and Malathion in Stored Wheat Grains

As shown in Fig. 1, fenitrothion combined with $\mathrm{PBO}$ and each phenothrin isomer was rapidly decomposed with respective half-lives of about 12 and 1.5 months at 15 and $30^{\circ} \mathrm{C}$. Malathion was decomposed a little faster than fenitrothion. The half-lives of malathion were about 8 and 1.1 months at 15 and $30^{\circ} \mathrm{C}$, respectively. Malathion was decomposed majorly to desmethylmalathion, amounting to $29 \%$ at its maximum, and to malathion monoacids and diacid, as shown in Table 6 . No malaoxon residue was detected throughout incubation at both temperatures. Volatile radioactive products increased gradually with time, amounting to $9 \%$ of the applied radiocarbon after 12 -month incubation at $30^{\circ} \mathrm{C}$. Most of these products were identified as ${ }^{14} \mathrm{CO}_{2}$. The unextractable residues (Bound in Tables) also increased with time, amounting to $20-50 \%$ of the applied radiocarbon after 12 months, but further characterization of these residues was not conducted.

The distribution pattern of ${ }^{14} \mathrm{C}$-malathion residues is similar to that of ${ }^{14} \mathrm{C}$-phenothrin residues, as shown in Fig. 2.

\section{DISCUSSION}

Phenothrin isomers were decomposed much more slowly than fenitrothion and malathion in stored wheat grains. The degradation of pyrethroids on stored wheat grains was studied under similar conditions. The respective halflives of pyrethrin I and allethrin in the grains with $15 \%$ moisture content at $30^{\circ} \mathrm{C}$ were 3 and 4 weeks. ${ }^{13)}$ The half-lives of bioresmethrin at $30-35$ and $20^{\circ} \mathrm{C}$ were $8-10$ and more than 26 weeks, respectively. ${ }^{14)}$ From these results, the degradation of phenothrin isomers in wheat grains seems to be much slower than these chrysanthemic esters.

Phenothrin isomers were mainly decomposed via cleavage of the ester linkage to PBalc which was subsequently oxidized to PBacid. PBacid was further converted to PBacid-Me. Both isomers in part underwent cleavage of the isobutenyl double bond to yield formyl- $t$ - and formyl-c-phenothrin, probably due to air oxidation. ${ }^{7}$ No trans/cis isomerization occurred during storage. Oxidation products at methyl groups of the isobutenyl moiety or ring hydroxylation products at $2^{\prime}-$ and $4^{\prime}$-positions of 3-phenoxybenzyl moiety, which were found in metabolic studies with rats, ${ }^{4-6)}$ were not detected in the present experiment. The degradation pathways for phenothrin isomers in stored wheat grains are proposed in Fig. 3. Rawlands ${ }^{13)}$ showed that pyrethrin I and allethrin were majorly de-

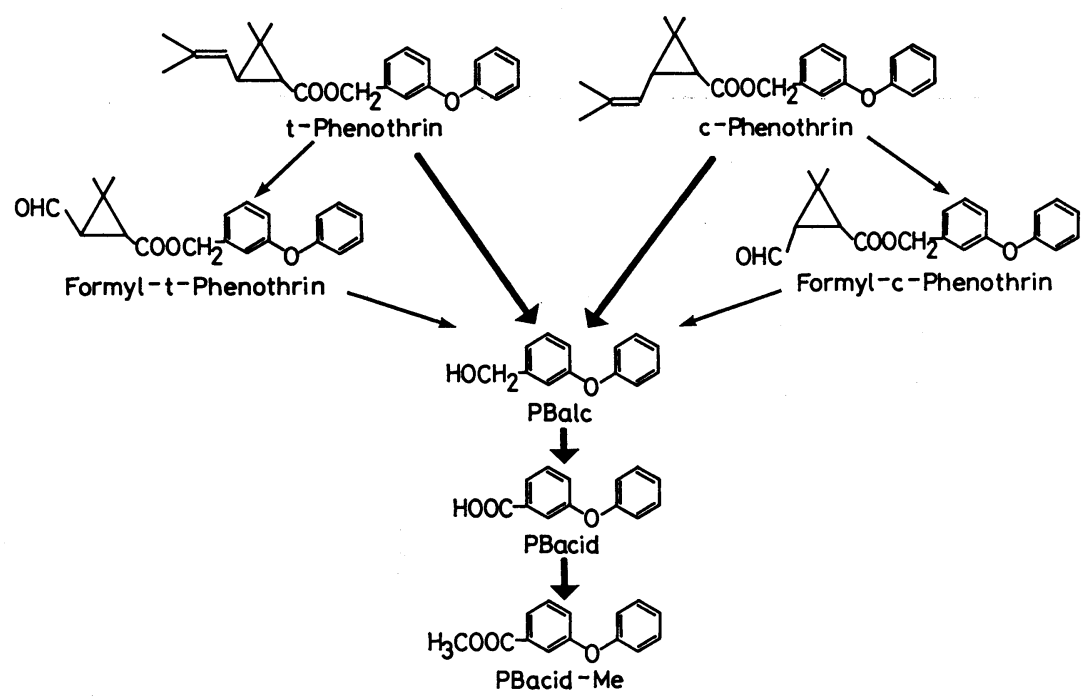

Fig. 3 Proposed degradation pathways for phenothrin isomers in stored wheat grains. 
graded to the chrysanthemic acid and the corresponding alcohols and no oxidative products were detected in stored wheat grains. From these findings it seems that little or no oxidative metabolism of chrysanthemic esters occurs in the first steps, hydrolytic degradation being the usual pathway in stored wheat grains. The preferential hydrolysis was observed in the decomposition of malathion in the present study, where no malaoxon was detected.

The radioautograms of sections of wheat grains (Fig. 2) show that little radiocarbon was located in endosperm, however the contents of phenothrin isomers in flour were relatively high. The gap is presumed to be due to contamination of seed coat at the crease area where the radiocarbon was localized into flour during our milling process. In a normal commercial flour milling, only a very small portion of the crease area will contaminate into flour. ${ }^{15)}$ In fact, the malathion contents in flour were $10-14 \%$ of those in wheat grains when a milling machine was used, as reported by Kawamura et al. ${ }^{16)}$ The malathion contents in flour obtained with our milling procedure were about $22 \%$ of those in wheat grains. ${ }^{17)}$ Therefore, in practice the contents of phenothrin isomers in flour appear to be lower than the figures that we found.

These laboratory findings suggest that phenothrin isomers applied to wheat grains seem to remain intact at seed coat and exhibit an excellent insecticidal activity against stored grain pests for a prolonged period. Most of the intact residues on the grains are likely to be removed during milling process and a low level of phenothrin residues will appear in flour or bread.

\section{REFERENCES}

1) K. Fujimoto, N. Itaya, Y. Okuno, T. Kadota \& T. Yamaguchi: Agric. Biol. Chem. 37, 2681 (1973)

2) J. H. Ardley \& G. R. H. Halls: Chemical Marketing and Economics Division of the American Chemical Society, Preprint, Honolulu, Hawaii, pp. 38-54, 1979

3) J. H. Ardley, M. Bengston, J. M. Desmarchelier \& P. Skidmore: J. Stored Prod. Res. in press

4) J. Miyamoto, T. Suzuki \& C. Nakae: Pestic. Biochem. Physiol. 4, 438 (1974)

5) T. Suzuki, N. Ohno \& J. Miyamoto: J. Pesticide Sci. 1, 151 (1976)

6) H. Kaneko, H. Ohkawa \& J. Miyamoto: $J$. Pesticide Sci. 6, 169 (1981)

7) K. Nambu, H. Ohkawa \& J. Miyamoto: J. Pesticide Sci. 5, 177 (1980)

8) M. Hazue \& T. Kamata: unpublished

9) T. Suzuki \& J. Miyamoto: Pestic. Biochem. Physiol. 8, 186 (1978)

10) S. W. Pixton: J. Stored Prod. Res. 3, 35 (1967)

11) Y. Takimoto, M. Ohshima \& J. Miyamoto: J. Pesticide Sci. 3, 277 (1978)

12) Y. Sato, J. Miyamoto \& S. Suzuki: BotyuKagaku 33, 8 (1968)

13) D. G. Rawlands: "Residue Reviews," ed. by F. A. Gunther, Vol. XXXIV, Springer-Verlag, New York, p. 116, 1971

14) FAO/WHO: "1975 Evaluation of Some Pesticide Residues in Food,” p. 67, 1976.

15) J. Moss: Private communication (1979)

16) K. Kawamura, M. Takeda, M. Uchiyama, K. Sakai \& H. Ishikawa: Shokuhin-Eiseishi 21, 70 (1980)

17) K. Nambu, Y. Takimoto \& J. Miyamoto: unpublished

要約

\section{フェノスリンの貯蔵中の小麦穀粒における分}

解

南部健二, 滝本善之, 宮本純之

${ }^{14} \mathrm{C}$ で標識したフェノスリンの（十)ートランスおよび (十)-シス体を水分含量 $11 \%$ の小麦穀粒におのおの 4 $\mathrm{ppm}$ の濃度で処理し, 15 または $30^{\circ} \mathrm{C}$ の暗所に貯蔵し た.トランスおよびシス両異性体は徐々に分解し, 12 力 月後には $30^{\circ} \mathrm{C}$ においてそれぞれ添加量の 79 および 87\% が小麦穀粒に残存していた. 両異性体ともおもに エステル結合の加水分解, ベンジルアルコールの安息香 酸一の酸化さらに安息香酸のメチル化を経て代謝され た.ピペロニルブトキサイドおよびフェニトロチオンと の混合処理によりフェノスリンの分解はいくぶん抑えら れた.フェノスリンとこれらの分解物は 12 力月間打も に種皮に存在し, 製粉により, 小麦粉打よびふすま中の 両異性体の残留量はそれぞれ 0.77 および $11.4 \mathrm{ppm}$ と なった.この小麦粉を製パンすると残留量は $0.57 \mathrm{ppm}$ に減少した。一方, ${ }^{14} C$ 一マラチオンは小麦穀粒中 15 お よび $30^{\circ} \mathrm{C}$ においてそれぞれ半減期 8 および 1.1 力月 の速度で分解し, デスメチル体，モノカルボン酸体，ジ カルボン酸体および ${ }^{14} \mathrm{CO}_{2}$ を生成した。 